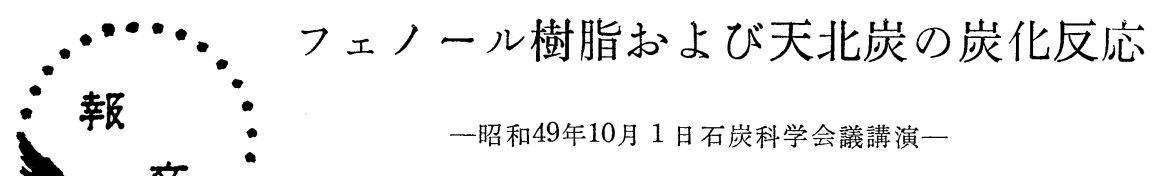

公害資源研究所 山下安正 - 大内公耳

\section{1. 緒言}

大内 ${ }^{1)}$ は種々の石炭を用い約 $100^{\circ} \mathrm{C}$ 間隔でガスを補 集し, $1,000^{\circ} \mathrm{C}$ ま゙タール, 水の測定も含めて, 質量 分析計を用いて分析を行ったが， $100^{\circ} \mathrm{C}$ 間隔であった ため, 詳細な変化を見ることができなかった。Fitzgerald $^{2)}$ はガスクロマトグラフを用い，大内より細か い温度間隔で連続的に分析を行ったが， $700^{\circ} \mathrm{C}$ までし か分析せず，またタール，水の測定は行ってはいな い。

一方, 石炭のモデル物質としてのフェノール樹脂の 炭化反応については, 同様の方法で Ōuchi ${ }^{3)}$ が, また 質量分析計イオン源内での 熱分解によるガス分析を G. P. Shulman ${ }^{4) 5)}$ がその他W. Schäfer 等( ${ }^{(1)}$ がガスクロ マトグラフで検討しているが，データーにかなりの差 が見られる。また，その熱分解反応機構に関してもな お充分満足する説明はなされていない。このため, 本実 験は, 試料としてフェノール樹脂を用い, 熱天科一ガ スクロマトグラフ同時測定装置により, 重量減少と発 生ガスの分析を同時に行って, 測定值, 測定温度の精 度を上げ, 測定温度間隔も細かくとると共に, 水の分 析を工夫し, また, 分解温度も $1,600^{\circ} \mathrm{C}$ を゙延ばし, 得られた結果よりフェノール樹脂の炭化反応を検討し た。また, 比較的フェノール樹脂に構造が類似してい ると考えられる天北炭の炭化反応について, フェノー ル樹脂の分解過程から類推して検討すると共に, その 構造についても推定を加えた。

\section{2. 実 験}

\section{$2-1$ 試料の調整}

試料として, フェノール・ホルマリン樹脂 $(\mathrm{Ph})$, 3-メチルフェノール・ホルマリン樹脂 (3-MPh), 3-5 ージメチルフェノール・ホルマリン樹脂 (3-5 DMPh), および天北炭を用いた。樹脂合成におけるフェノー ル・ホルマリン比, および樹脂と天北炭の元素分析值 を Table 1 に示す。

樹脂の合成に際しては $23 \%$ アンニア水溶液を触媒 として, フェノール 1 モルに対して $10 \mathrm{~m} l$ を加え, 温浴上で $90 \sim 98^{\circ} \mathrm{C}, 3$ 時間加熱して, 初期縮合反応
Table 1 The ratio of phenol to formaldehyde in resins and ultimate analyses of resins and brown coal

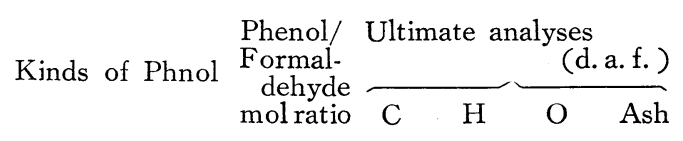

$\begin{array}{llllll}\text { Phenol } & 1: 2 & 76.5 & 5.3 & 17.6 & -\end{array}$

3-Methyl Phenol $\quad 1: 1 \quad 76.7 \quad 5.9 \quad 17.4 \quad-$

$\begin{array}{ccccccc}\text { 3-5 Dimethyl } & 1: & 1 & 81.6 & 8.6 & 10.4 & -\end{array}$

$\begin{array}{llllll}\text { Tempoku coal } & - & 70.4 & 4.7 & 24.9 & 1.5\end{array}$

を行なわせ, 後 $130 \sim 140^{\circ} \mathrm{C}, 8 \sim 10$ 時間, 空気浴中で 熱硬化した。5 10 mesh の天北炭は比重 1.3 1.4の ベンゼン一四塩化炭素溶液で浮選して，ビトリットを 集めると共に脱灰してから $100 \mathrm{mesh}$ 以下に粉砕し， 塩化カルシウム入りデシケーターに保存し, 使用に先 立ち窒素雾囲気下 $100^{\circ} \mathrm{C} に 1$ 時間放置して用いた。

2-2 実験装置

実験装置のフローチャートをFig. 1 に示した。天科 および熱分解炉に流寸雾囲気ガスは，まず $400^{\circ} \mathrm{C}$ の還 元銅で酸素を，次に液体窒素冷却トラップで水分を除 去精製した後, 天秤および熱分解炉に導入した。この 両者は充分に除去しておかないと，特に高温部におい て大きな誤差を生じるので, 雲囲気ガス流量を大きく 変えても, 分析值が一定となるまで精製する必要があ る。発生ガス測定に㧤いて, $1,000^{\circ} \mathrm{C}$ までは, 水以外 は熱天科ーガスクロマトグラフ 測定装置を用いて，1

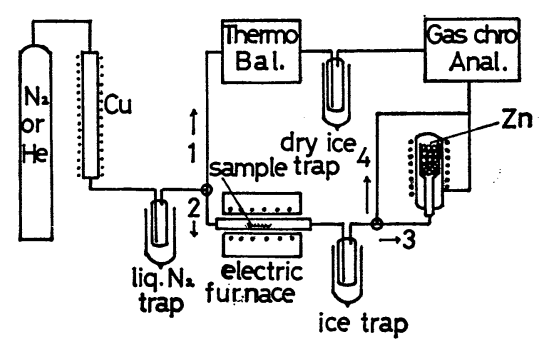

Fig. 1 Apparatus for the measurment of decomposed gases 
の径路により分析し, 分解ガス中に含まれる水および タール，または低分子分解生成物 (LMS) はドライア イスで泠却除去した。水は 2 の径路により, 熱分解炉 を別にし，また，感度を上げる目的で, 発生した水を 3 の径路から $400^{\circ} \mathrm{C}$ に熱した亜鉛をつめた水分解炉を 通して水素に変換後, ガスクロマトグラフで分析し た。4の径路は測定時以外に発生ガスによる亜鉛の劣 化を防ぐためのバイパス径路である。 $1,000^{\circ} \mathrm{C}$ から $1,600^{\circ} \mathrm{C}$ における水素の測定は, アルミナ製血, およ びアルミナ管を用い, 径路 3 の亜鉛分解炉を除いた方 法で測定した。

試料量は，水素および水については $10 \mathrm{mg}$, メタ ン, 一酸化炭素, 二酸化炭素については $50 \mathrm{mg}$ を用 いて測定した。熱天科，および分解炉の昇温速度は $10^{\circ} \mathrm{C} / \mathrm{min}$, 雲囲気ガスの流量は $50 \sim 80 \mathrm{ml} / \mathrm{min}$ とし, 分解ガス採取温度間隔は $20^{\circ} \mathrm{C}$, 採取量は $2 \mathrm{~m} l$ とし た。なお, 雰囲気ガスはガスクロマトグラフのキャリ ヤーガスと同様のものを用いるため, 水素と水は窒素 を, メタン, 一酸化炭素, 二酸化炭素はへリウムを用 いた。ガスクロカラムとしては, 水素, メタン, 二酸 化炭素には活性炭を用い, カラム温度 $120^{\circ} \mathrm{C}$ で, 一酸 化炭素, メタンにはモレキュラーシーブ $5 \mathrm{~A}$ をカラム 温度 $80^{\circ} \mathrm{C}$ で共に長さ $1.5 \mathrm{~m}$, 径 $2.5 \mathrm{~m} / \mathrm{m}$ のカラム を使用し，キャリヤー流速 $40 \mathrm{ml} / \mathrm{min}$ で測定した。 天秤, ガスクロマトグラフ分析における測定誤差は, それぞれ $\pm 1.0 \% ， \pm 2.0 \%$ であった。なおタール およびLMS は, 直接測定した值ではなく, 各温度に おける発生ガス量を重量減少より差し引いた残りを LMS またはタールとした值である。またこれら LMS およびタールは, 試料の基本単位がそのまま切 れて出て来たもので, 元素分析值はほぼ原試料に等し いと仮定した。図に示された発生量はこのため, 各発 生温度におけるタール, LMS 量に対し補正し, 原試 料がタールや LMS を発生しないで分解したとする時 の值を示してある。

\section{3. 結果および考察}

樹脂および天北炭の熱処理温度に対する重量変化を Fig. 2 に示した。重量減少率は $\mathrm{Ph}$ の 39\% から 3-5 $\mathrm{MD} \mathrm{Ph}$ の73\%えと増加している。これは $\mathrm{Ph}$ では三 次元構造が発達し， 3-5 DM-Ph では側鎖の立体障害 のため線型低分子に止まるためと考えられる。後に見 るように LMS の量もこれに比例する。天北炭は重量 減少からだけみると, $\mathrm{Ph}$ に類似した変化を示し, 分 子構造が $\mathrm{Ph}$ に似て三次元的なものであろらと考えら れる。

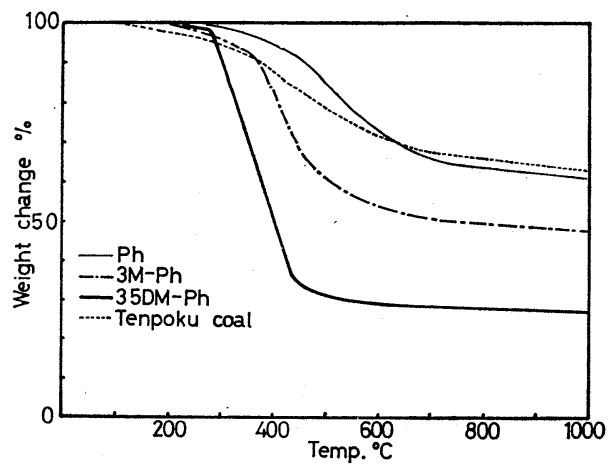

Fig. 2 Weight change during heat treatment

Fig. 3 6 は, 各試料の熱処理温度に対する熱分解 ガスの変化を示す。

これらの結果は, 大内等 ${ }^{3}$ のデーターとほぼ一致し

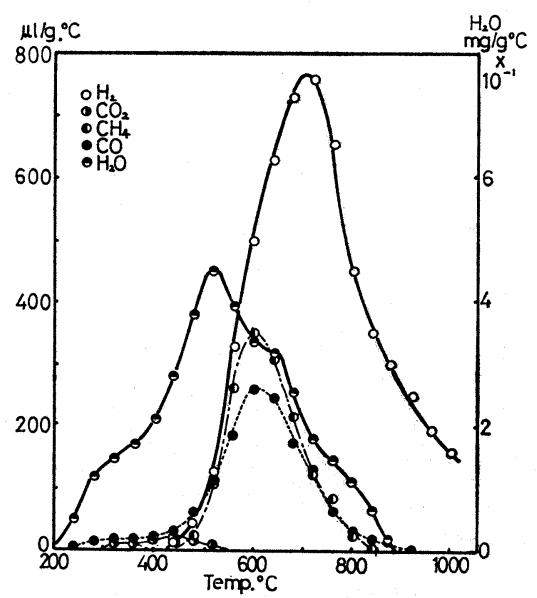

Fig. 3 Production rate of gases and water of phenol resin

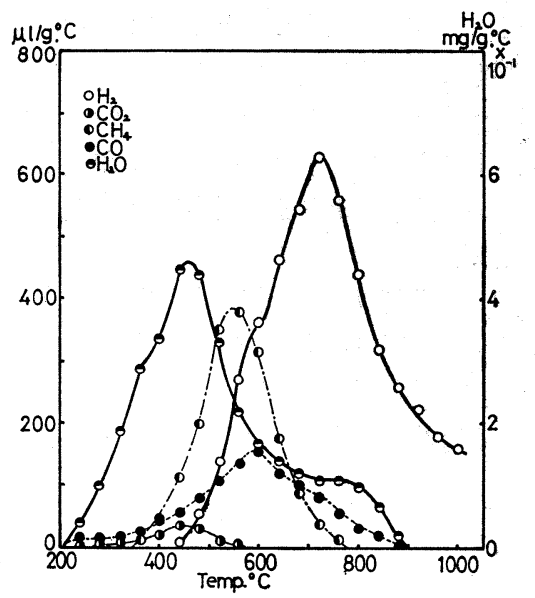

Fig. 4 Production rate of gases and water of $3 \mathrm{mtlhylphenol} \mathrm{resin}$ 


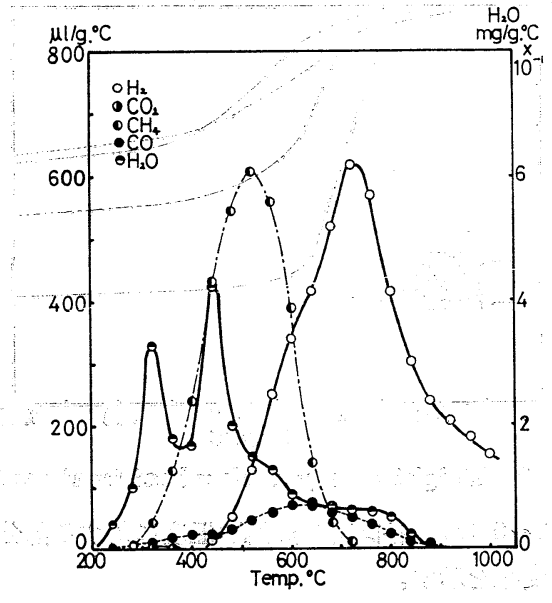

Fig. 5 Production rate of gases and water of 3,5 dimethylphenol resin

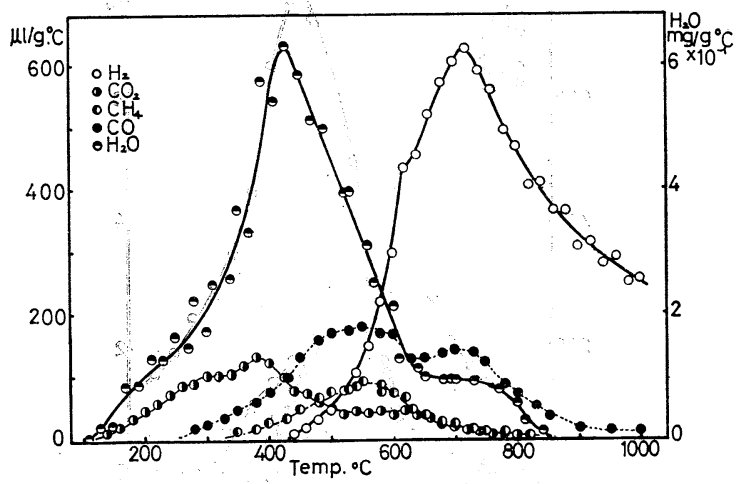

Fig. 6 Production rate of gases and water of Tempoku coal

た值を示している。発生ガスとしてはメタン，一酸化 炭素, 炭酸ガス, 水以外にもエタン, フェノール類等 他の炭化水素も発生するものと思われるが，エタンは 測定限界外にあり，フェノール類等の重い炭化水素は すべてタールまたは低分子物質中に含まれる。

熱分解ガスのおのおのの発生状態を各試料について 検討すると, 分解度応は最初脱水反応が $250^{\circ} \mathrm{C}$ 付近か ら生じる。この脱水反応は， 3-5 DM-Ph は 330 およ び $450^{\circ} \mathrm{C}$ に $3 \mathrm{M}-\mathrm{Ph}$ は $460^{\circ} \mathrm{C}$ 付近に, $\mathrm{Ph}$ は $520^{\circ} \mathrm{C}$ 付近に, 天北炭は $430^{\circ} \mathrm{C}$ 付近に発生ピークを示してい る。しかし，後述するよらにこれらの曲線はいくつか の脱水反応が重なり合っているものと考えられる。メ タンはフェノール分子中に含まれるメチル基の数が多 くなるにしたがい発生温度が $600^{\circ} \mathrm{C}(\mathrm{Ph})$ から $.560^{\circ} \mathrm{C}$ (3-M-Ph), $520^{\circ} \mathrm{C}(3-5 \mathrm{DM}-\mathrm{Ph})$ と低温側にずれ，
発生量もそれに比例して増加することから， $500^{\circ} \mathrm{C}$ 付 近のメチル基の分解によるメタン生成と， $600^{\circ} \mathrm{C}$ 付近 におけるメチレン基等の分解によるメタン生成の $2 つ$ の反応が考えられる。.天北炭では発生温度は Ph と 3 $\mathrm{M}-\mathrm{Ph}$ の中間にあり, 量が著しく少ない。CO は樹脂 3 試料とも $600^{\circ} \mathrm{C}$ 付近を発生ピークとしているが， $\mathrm{Ph}, 3 \mathrm{M}-\mathrm{Ph}, 3-5 \mathrm{DM}-\mathrm{Ph}$ の順で発生量は減少して いる。一酸化炭素分解が. $\mathrm{Ph}$ ではメタン. 水素とほ ぼ同じ温度から発生することから，これら成分は相互 に何らかの関連した分解反応から発生したのではない かと推測される。天北炭では $\mathrm{CO}$ の分解温度が樹脂類 よりやや低温にずれると共に，樹脂では不明膫な高温 部にさらに極大発生が存在する。炭酸ガスは発生量は 樹脂では他の発生ガスに比べ多くない。窒素雲囲気下 で合成したフェノール樹脂からは，炭酸ガスはほとん ぞ発生しないわことから空気浴で熱硬化中に酸 化帛 しメチレン基, または残存メチロール基から カルボキシル基が生じ, これが分解して出て来た ことによると考えられる。これに対し，天北炭で は遙かに多くの炭酸ガスが発生し, 発生温度も高 温まで続く。水素は試料の種類が変っても，発生 量は余り変化せず，また発生ピーク温度も $720^{\circ} \mathrm{C}$ 付近と変らず，炭化過程における多環化反応がど の試料についても類似していることを示してい る。

以上の樹脂の分子構造の違いと, 発生ガスの状 態の差から，天北炭の分解ガス発生状態を検討す ると，メタン，水，一酸化炭素など，量を別にす ればかなり $\mathrm{Ph}$ に類似した傾向を示している。こ れは天北炭が水酸基, カルボキシル基, わずかな アルキル基，キノンあるいはナフテン構造等をもつ芳 香族核をメチレン等の脂肪族構造で結んだような分子 構造から成立っていることを類推させる。天北炭の酸 素含量 $24.9 \%$ と含酸素発生ガス中の全酸素量 $24.1 \%$ と はほぼ見合っている。

Fig. 7 は樹脂類について $1,000^{\circ} \mathrm{C}$ 以上 $1,600^{\circ} \mathrm{C}$ まで の水素発生量を示している。これからも明かな様に $1,600^{\circ} \mathrm{C}$ 付近でもまだ水素を発生し，高温では $\mathrm{Ph}$, $3 \mathrm{M}-\mathrm{Ph}, 3-5 \mathrm{DM}-\mathrm{Ph}$ の順にわずかに増えている。 このことは $\mathrm{Ph}, 3 \mathrm{M}-\mathrm{Ph}, 3-5 \mathrm{DM}-\mathrm{Ph}$ の順に黒鉛 様結晶子の発達がよくなる ${ }^{910) 11)}$ 事と関連し極めて興 味がある。1 $1,600^{\circ} \mathrm{C}$ 付近での再増加の傾向は測定精度 から余り明確にいらことはできないのでさらに精度を 上げて測定確認する必要があるが, $1,500^{\circ} \mathrm{C}$ 近边から 磁気係数9，X線等 ${ }^{10111)}$ から見られるように結晶子が 


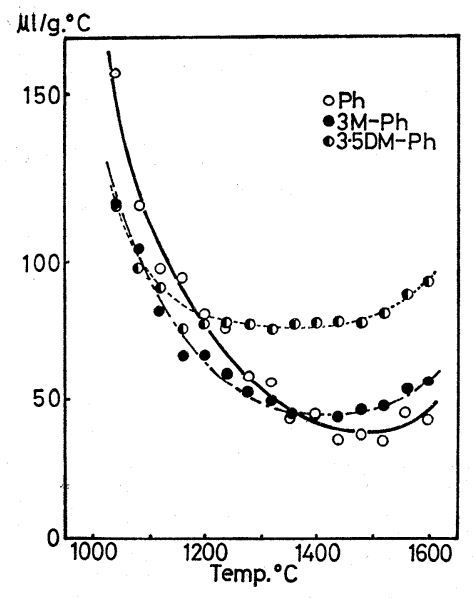

Fig. 7 Production rate of hydrogen in high temperature range

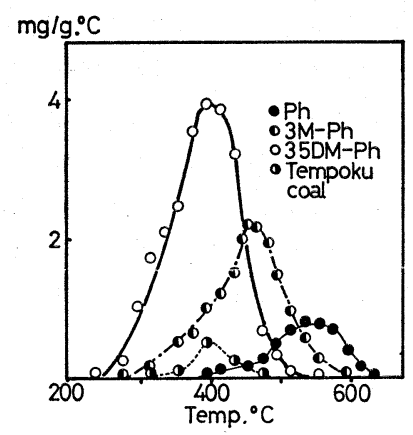

Fig. 8 Production rate of low molecular substances or tar

急速に大きくなる事と何らかの関係があるかもしれな W。

Fig. 8 は各温度における発生ガス量を重量減少より 差し引いた残りを低分子物質またはタールとして示し た值である。重量減少曲線同様樹脂の分子構造により 生成量にかなり大きな差があらわれている。三次元構 造をもつ $\mathrm{Ph}$ は約10\%の量であり，LMS ができにく い。線状低分子と考えられる 3-5 DM-Ph は63\%と かなり大きな值を示し, 熱分解により容易に低分子生 成物ができることを示している。タールの量や重量減 少曲線から推測すると, 天北炭は $\mathrm{Ph}$ に近い三次元構 造をもつと考えてよいであろう。

次に炭化過程における発生ガスの反応速度論的な解 析を行い，さらに詳細な炭化反応を検討した。石炭に ついてのこの種の解析は Fitzgerald 等常により論じら れているが，本報告でもこの手法を用いて解析した。 炭化反応によって発生するガスが一次反応によって生
ビると仮定すると，(1) 式が成り立つ。

$$
d v / d t=K\left(v_{0}-v\right)
$$

$v_{0}$ は全発生ガス量, $v$ は $t$ 時間における発生量, $K$ は反応速度定数である。この速度定数と反応温度の関 係を示す Arrhenius の式より，(1) 式は

$$
d v / d t=K_{0}\left(v_{0}-v\right) \exp (-E / R T)
$$

$E$ は見掛けの活性化エネルギー, $R$ は気体定数であ る。 $K_{0}$ は頻度因子であり, 式 (2) より $\ln (d v / d t) /$ $\left(v_{0}-v\right)$ と $1 / T$ の関係をプロットした図の切片に相 当する。活性化エネルギー $E$ は図の勾配から計算に より求めることができる。Fig. 8 は分解ガス中のメタ ンについての反応速度定数と $1 / T$ の関係を示した。

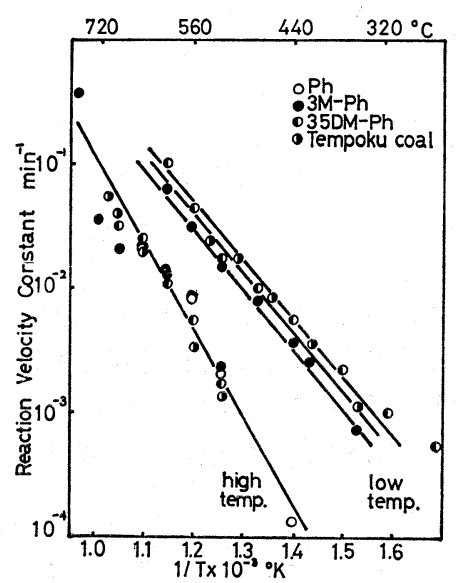

Fig. 9 Arrhenius diagram for methane

$3 \mathrm{M}-\mathrm{Ph}, 3-5 \mathrm{DM}-\mathrm{Ph}$, 天北炭についてはメタン発生

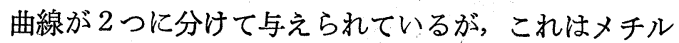
基を全くもたない $\mathrm{Ph}$ の場合 $600^{\circ} \mathrm{C}$ の付近をピークと した曲線が得られたため, これらの試料についても $600^{\circ} \mathrm{C}$ 付近を山とする曲線と，500 $\mathrm{C}$ 付近をピークに した曲線の $2 つ に$ 分け, それぞれについて反応速度定 数を求めたものである。図からも明かな様に低温側に おいてはかなりよい直線性を示し, しかも $3 \mathrm{M}-\mathrm{Ph}$, 3-5 DM-Ph, 天北炭の三種共平行で同じ見掛けの活 性化エネルギー值 $22.9 \mathrm{kcal} / \mathrm{mol}$ を与える。また, 高 温側におけるピークは多少のばらつきはあるが, 三種 共 $\mathrm{Ph}$ とほぼ同じ傾向を示し， $34.8 \mathrm{kcal} / \mathrm{mol}$ の見掛 けの活性化エネルギーが得られた。この結果から, 上 記の如く $3 \mathrm{M}-\mathrm{Ph}, 3-5 \mathrm{DM}-\mathrm{Ph}$, 天北炭でメタン発生 を二種に分ける事は正しく, 脱メタン化反応は $500^{\circ} \mathrm{C}$ 付近のメチル基からのメタン脱離反応とメチレン基あ るいは芳香環からの脱メタン化反応に分けることがで き, 反応のしやすさの違いが見掛けの活性化エネルギ 
一の違いに表われているものと考えられる。

同様の解析を一酸化炭素, 水, 水素について行った 結果を Table 2 に示す。

Table 2 Apparent activation energy of produced gases

$\begin{gathered}\text { Produced } \\ \text { gases }\end{gathered}$
$\begin{gathered}\text { Maximum } \\ \text { temperature } \\ \left({ }^{\circ} \mathrm{C}\right)\end{gathered}$ $\begin{gathered}\begin{array}{c}\text { Apparent } \\ \text { activation } \\ \text { energy } \\ \text { (kcal/mol) }\end{array} \\ \mathrm{H}_{2} \mathrm{O} \\ \mathrm{CO}\end{gathered} \quad\left\{\begin{array}{cc}320 & 7.3 \\ 500 & 17.4 \\ 760 & 36.6 \\ 550 & 13.7 \\ \mathrm{H}_{2} & \left\{\begin{array}{c}720 \sim 780 \\ 720\end{array}\right.\end{array}\right.$

三種の樹脂および天北炭の水の発生曲線を見ると， $320^{\circ} \mathrm{C}, 500^{\circ} \mathrm{C}, \quad 760^{\circ} \mathrm{C}$ に最大をもつ三領域に分けら れる。更に $500^{\circ} \mathrm{C}$ と $760^{\circ} \mathrm{C}$ の間にもう 1 つの分解があ るように見えるが，これは余り明らかでないのでこ こでは上記の三領域に分けて見掛けの活性化エネルギ 一を求めた。 $320^{\circ} \mathrm{C}$ に最大を持つ脱水反応は, 赤外の $3,400 \mathrm{~cm}^{-1} \mathrm{OH}$ 吸収が $400^{\circ} \mathrm{C}$ を境にしてその減少傾 向を異にする事から考えて ${ }^{15)}$ 樹脂の末端メチロール基
による熱硬化反応の続きと考えられる。見掛け活性化 エネルギーが低い事も妥当であろら。二番目の $500^{\circ} \mathrm{C}$ 付近における主脱水反応は, Fig. 9 の如き図における プロットが $600^{\circ} \mathrm{C}$ 付近で折れた直線となっていること

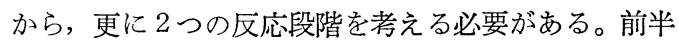
は水酸基を含むエーテル生成等の反応と考えられる。 後半の不明膫な脱水反応と $760^{\circ} \mathrm{C}$ に極大を持つ脱水と についてはなお明らかでないが，2,6-diphenyl poly phenylene oxide の熱分解では $550^{\circ} \mathrm{C}$ と $800^{\circ} \mathrm{C}$ に明確 に分離した脱水反応が見られるので12)，1 度生成した エーテル構造の再分解によるのではないかと推定され る。一酸化炭素では低温部の裾があるが, 窒素中で熱 硬化した $\mathrm{Ph}$ ではこれが現われず酸化によるものであ るので,この部分は作図により除いて計算を行った。 また，700 $800^{\circ} \mathrm{C}$ 近辺も膨らんでおり，2つの反応 と見られるのでこれも 2 部分に図上で分離して計算 を行ったが精度は低い。上述の 2,6-diphenyl poly phenylene oxide が $600^{\circ} \mathrm{C}$ と $800^{\circ} \mathrm{C}$ に一酸化炭素分解 極大点を持ち, またビオランスロンの如き多環芳香族 キノンも $700^{\circ} \mathrm{C}$ に一酸化炭素の発生極大を有すること から ${ }^{12)}$, 先に生成したエーテルまたはキノン構造が再 分解しトロピリウム型 7 員環を経て脱 $\mathrm{CO}$ する反応が 考えられ，これに水酸基からのトロピリウム環経由の

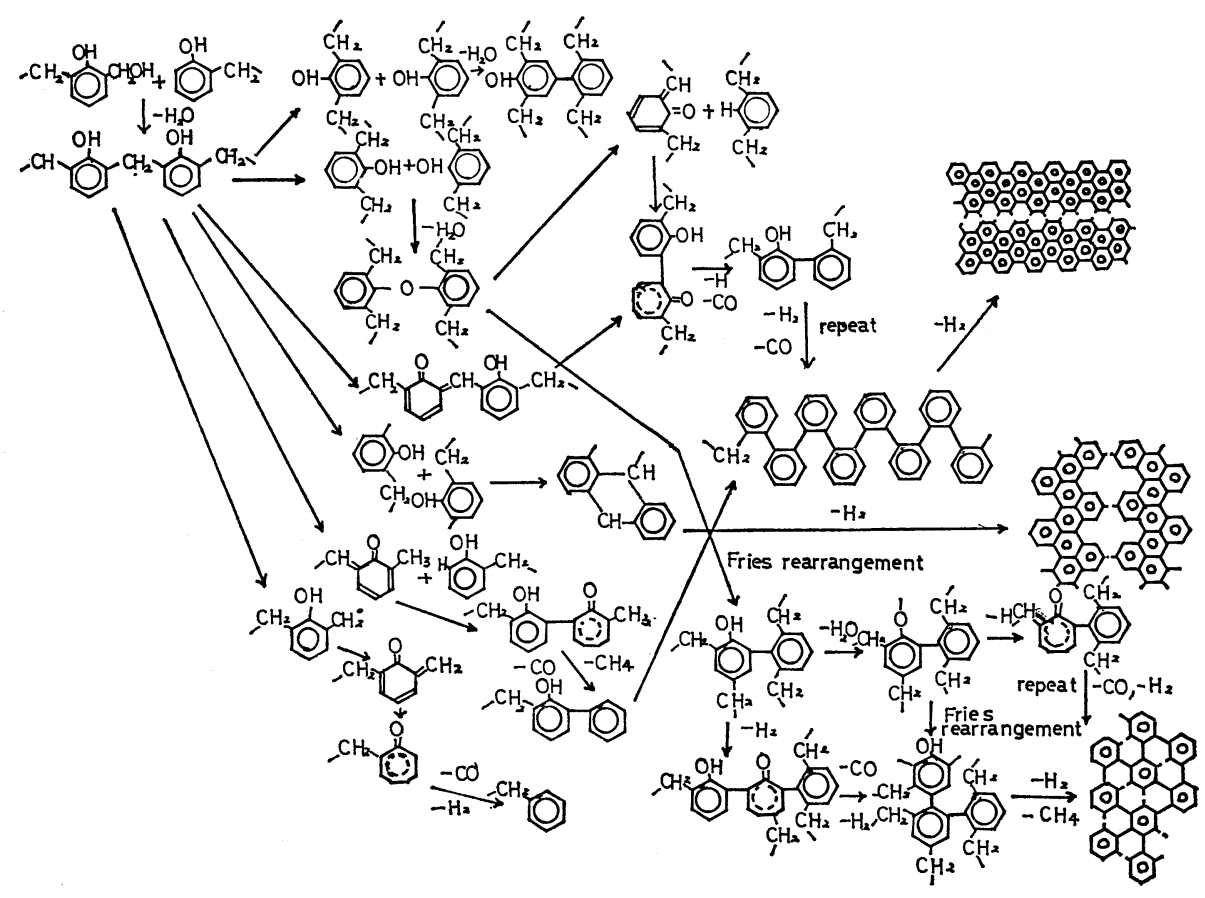

Fig. 10 Decomposition mechanism of $\mathbf{P h}$ 
脱 CO が重なっているのではないかと推定される。

水素のプロットは必ずしもよい直線とならず高温部 に向って若干彎曲している。Table 2 の数值は低温域 の值である。脱水素反応は生成ナフテン環の脱水素と 芳香族環同志の脱水素による縮合とがあり, 特に後者 では環の拡大に伴い見掛けの活性化エネルギーも当然 変化してくるものと予想されるので, Fig. 9 の如きプ ロットが直線的とならないのは理解し易い。さらに最 も低温部にはトロピリウム環生成の時の脱水素も加わ っているであろう。なお計算された活性化エネルギー 值恃 D. Fitzgerald ${ }^{2)}$ ，N. Berkowitz ${ }^{13) 14)}$ による值とほ ぼ同じ值であった。

以上の如き分解機構の推定を $\mathrm{Ph}$ について一括して Fig. 10 に示す。赤外による研究では $\mathrm{C}=\mathrm{O}$ 基 $(1,660$ $\left.\mathrm{cm}^{-1}\right)$ および $-\mathrm{CH}_{3}$ 基 $\left(1,385 \mathrm{~cm}^{-1}\right)$ の生成がそれ ぞれ $500^{\circ} \mathrm{C}$ および $550^{\circ} \mathrm{C}$ を最大として見られ $\left.{ }^{15}\right) \mathrm{Fig} .10$ の反応機構の傍証となる。また, 赤外の $1,320,1,200$ $\mathrm{cm}^{-1}$ の吸収で推定される Xanthene または diphenylene oxide 型の構造15) も一部寄与していると思われ るが，反応自体は Fig. 10 と大差ないので図には繁雑 を避けて示していない。また図には個々の局部的な反 応のみを示したのであるが，実際には $400 \sim 500^{\circ} \mathrm{C}$ に おけるメチレン結合の切断による次の如き連鎖反応が 重要なものと考えられ, この繰返しにより, 次第にべ ンゼン環同志の直接結合が増し, さらに脱水素により 芳香環の拡大が生じる。

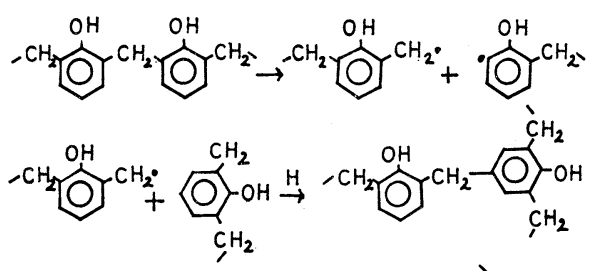

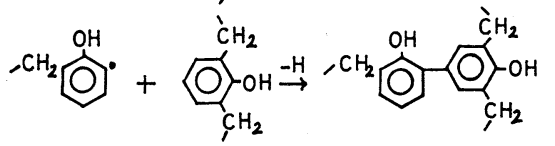<smiles>CCc1cccc(C[CH+]CCCc2cccc(O)c2CCCCCc2ccccc2O)c1</smiles><smiles></smiles>

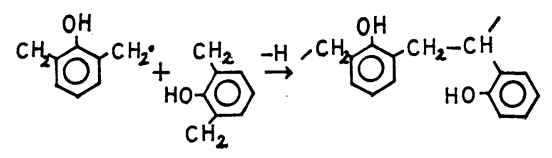

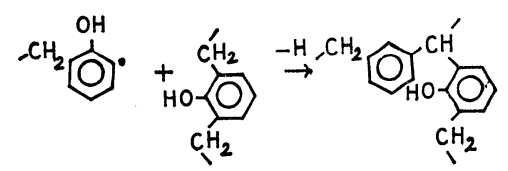

以上の如き連鎖反応と Fig. 10 の局部反応の組合せ で複雑な炭化反応が進んでいくものと考えられる。

3-5 DM-Ph の場合は Fig. 10 および上式の連鎖反 応類似の反応と同時に次の如き反応が生ずる ${ }^{3) 15)}$ ので 黒鉛様結晶子の発達が $\mathrm{Ph}$ に比べて遙かによくなる。

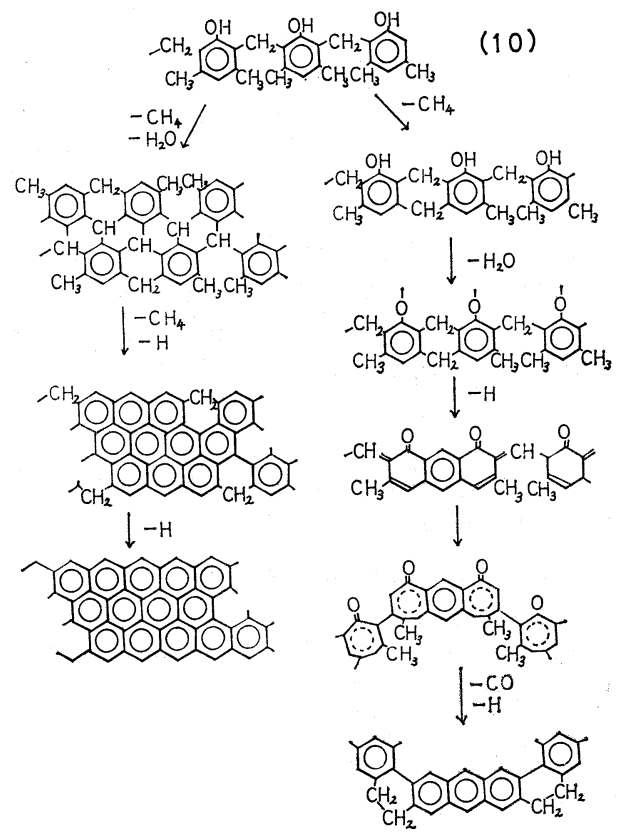

この反応の前段はメタン発生温度から見るとすでに $300^{\circ} \mathrm{C}$ 近辺から生じていると見られ, しかむホルムア ルデヒドと 3-5ジメチルフェノール 1:1 モル比を用 いる時はメチル基の立体障害のため縮合が進み難く低 分子量に止まるので $300 \sim 400^{\circ} \mathrm{C}$ で液体状になるため, 生成した平面分子が相互に平行に液晶状に並び易くい わゆるメソフェースの分離を生ずる。顕微鏡観察によ ると球体出現温度は $380^{\circ} \mathrm{C}$ 近辺にあり ${ }^{16)}$ メタン発生曲 線からみて極めて妥当な温度といえる。 $3 \mathrm{M}-\mathrm{Ph}$ は $\mathrm{Ph}$ と 3-5 DM-Ph のちょうど中間に存在し, ある程度 メチル基の脱離による（10）式類似の縮合環化が生ず る。 $1,000^{\circ} \mathrm{C}$ における元素組成を試料の元素分析值か ら全発生ガス分を除いて求めると $\mathrm{Ph}$ の場合 $\mathrm{C}_{13} \mathrm{H}_{2}$ と なり, ペリ型の単環と仮定するとベンゼン環約100個, 半径約 $27 \AA$ 程度に相当する芳香族化合物となり, 長 
方形にしてもべンゼン環数にそれ程大きい違いはな い。X線測定では大内 ${ }^{10)}$ の值が約 $20 \AA$, 小林ら ${ }^{11}$ の 值が約 $30 \AA$ であるので極めてよい一致といえる。

天北炭においても生起している反応様式は全く同様 と考えられる。Ph に比し水素, 一酸化炭素の発生量 はほぼ同じである。一酸化炭素では高温部の反応に与 る量が多いが、エーテルまたはキノン構造に原因があ るものと考えられる。炭酸ガスは著しく多いが，これ は若年炭としては当然であろう。ただ高温部における 発生に対してはなおその原因に疑問がある。メタン生 成量は温度範囲は $\mathrm{Ph}$ とほぼ同じであるが量が著しく 少なく, アルキル側鎖があまりない事，ナフテン環の 存在, 芳香環がベンゼン環より大きいものである事, 炭酸ガス発生量の多い事による相対的減少等の原因が 考えられる。水の発生は $3 \mathrm{M}-\mathrm{Ph}$ に最むよく類似し ているが量的には $1 / 3$ 程度多くなる。 $200^{\circ} \mathrm{C}$ 辺の局は メチロール縮合のよらな反応が生じているのではない かと予想される。亜炭, 褐炭等の乾燥脱水はしばしば 問題にされ化学結合水の脱水等と考えられているが樹 脂脱水曲線と比較した時前記の如く考えた方がよいで あろら。

天北炭の熱収支曲線は全般的に発熱側にあり, 特に $370^{\circ} \mathrm{C}, 600^{\circ} \mathrm{C}$ 近辺に極大点を有する ${ }^{17)} 。 370^{\circ} \mathrm{C}$ の極大 は発熱の水発生極大温度とほぼ一致する。 $550^{\circ} \mathrm{C}$ の一 酸化炭素の吸熱はメタンの発熱と相殺されると考えら れ，従って $500^{\circ} \mathrm{C}$ からは水素の 発熱が主導するが, $700^{\circ} \mathrm{C}$ では高温部一酸化炭素の吸熱により吸熱側に近 ゔき, そのため $600^{\circ} \mathrm{C}$ 付近㥛大を生ずるものと理解 される。

\section{4. 結 論}

以上の実験結果ならびに考察をまとめると，

（1）熱天雬一一ガスクロ同時測定装置を用い，フェ ノール樹脂, 天北炭の熱分解ガスを $1,600^{\circ} \mathrm{C}$ まで 連続的に再現性よく測定することができた。

(2) フェノール樹脂の炭化反応について発生ガスの 主成分である $\mathrm{CH}_{4}, \mathrm{H}_{2} \mathrm{O}, \mathrm{H}_{2}, \mathrm{CO}, \mathrm{CO}_{2}$ の測 定だけでもかなりよく分子構造の違いによる差を 示すことができた。
(3) 天北炭の発生 ガス 曲線を，フェノール樹脂の それと比較し， 天北炭の 化学構造 を推測すると $\mathrm{COOH}, \mathrm{OH}$, キノンおよびナフテン構造, そし てわずかなアルキル基を持つ芳香核等を脂肪族側 鎖で結合した高度の三次元構造のものと考えられ る。

(4) 樹脂類および天北炭の分解ガスについて反応速 度論的な解析をした結果, 脱 $\mathrm{CO}$, 脱 $\mathrm{H}_{2} \mathrm{O}$, 脱 $\mathrm{CH}_{4}$ 等が数段階に分れた反応をしていることが 示され，またその反応機構について詳紐な推察を 加えた。

\section{文献}

1) 大内, 本田, 燃協誌, 40, 845 (1961)

2) D. Fizgerald, D. W. Van Krevelen, Fuel, 38, 17 (1959)

3) K. Ouchi, H. Honda, Fuel, 38, 429 (1959)

4) G. P. Shulman, Polymer Letter, 3, 911 (1965)

5) G. P. Shulman, H.W. Lochte, J. Appl. Poly. Sci., 10, 619 (1966)

6) W. Schäfer,Ph. D. Thesis, Karlsruhe University, W. Germany, 1969, E. Fitzer, W. Schäfer, Carbon, 8, 353 (1970)

7）山下, 大内, 未発表

8) T. Robert, Thermal Stability of Polymer, Marced Dekker, New York, p. 459 (1970)

9) 本田, 大内, 日化誌, 76, 154, 361 (1955)

10) 大内, 本田, 日化誌, 77, 147 (1956)

11) K. Kobayashi, S. Sugawara, S. Toyoda, H. Honda, Carbon, 6, 359 (1968)

12）山下, 大内, 未発表

13) N. Berkowitz, W. den Hertog, Fuel, 41, 507 (1962)

14) W. J. Mullin, N. Berkowitz, Fuel, 47, 63 (1968)

15) K. Ōuchi, Carbon, 4, 59 (1966)

16) Y.Sanada, T.Furuta, H. Kimura, H. Honda, Fuel, 52, 143 (1973)

17）山下, 大内, 燃協誌， 49, 890 (1970)

\section{〔討論〕}

座長 長谷川義久 (北開試)

宮津（日本鋼管） 天北炭を Ash free にした目的
は。

山下 石炭そのものの変化を知りたかったのでAsh が熱分解過程で触媒の役割をするのをおそれた。

宮津 熱分解残渣の形状は。 
山下 石炭は 100 mesh 以下に粉砕しており粉状で ある。3 5 DMPh の場合は溶けてコークス状となっ て残る。

座長 石炭の脱灰の方法は。

山下 比重液で分離した。

西野 (北開試) 装置について, Zn をつめた水分 解炉と熱天科の機構を教えてほほい。

山下 水分解炉はマススペクトルで使われている水 を分解したり $\mathrm{HD}$ や $\mathrm{D}_{2}$ を水にして測定する装置を 借用した。装置は $5 \sim 7 \mathrm{~mm} \dot{\phi}$, 高さ $50 \mathrm{~mm}$ でこれに 30 mesh の Zn をつめてある。熱天科は雲囲気調整装 置とガス流量調整装置が付属している理学電気の卓上 型熱天科である。ガスクロとの接続はガラス細工で自 作した。

前河 (北開試) 天北炭が 3 次元構造を有するとの 考えに至った理由は。脱水反応, メタン, $\mathrm{CO}$ 生成の データからはこのような結論が出し難いと思うが。

山下 他の解重合等の実験結果も考慮すると天北炭 はリグニンの多少変化したような構造を持つと考えて いる。つまり芳香族（主としてベンゼン環）をメチレ ン等で結合した 3 次元結合していると考えている。

前河 その類似性の類推はわかるが, 脱水反応をみ ても天北炭がとくに次元構造の樹脂に近いとはいえな いのではないか。

山下 Fig. 2 と Fig. 8 において重量減少曲線が似 ておりまたタール量 (LMS) が両方とも少ない。分解 して出てくるのは周辺の $\mathrm{OH}, \mathrm{COOH}$, メチレン結合 であり，2次元結合の場合はタール発生量はすっと多
くなる筈である。

前河 天北炭と樹脂とは構造形が同じかとうかわか らす，同じ構造形でないとそのような比較が困難であ る。また Fig. 8 で LMS の発生温度範囲やガスの発 生状態も異っている。また p.79 の結論 (3) で結合 が脂肪族側鎖であるとした根拠は。

山下 メタンが発生すること, また伊牟田らが解重 合の研究でメチレンおよびエチレン結合の存在を推定 していることを考えに入れた。

山田 (泰) (九工試) Fig. 3でメタンが生じてく るのはフェノールとフェノールを結合しているメチレ ン橋が切れてでてくると思らが, 3-MPh や 3-5DMPh のようにメチレン結合の隣に $\mathrm{CH}_{3}$ 基が存在する場合, メチレン橋は切れるのかそれとも環化するのか。

山下 Fig. 10 と式 (10) を見て頂きたい。これは マスのイオン分解を参考にしてこの化学反応を考えた が，まず側鎖のメチル基がきれてそのあとラジカル反 応が進んで環化していく。メチレン橋はエネルギーが 高い状態でなければきれない。それでトロピリウムの 形を経過するとも考えられる。

上田（北開試）エタン, プロパン, $n$-or iso-ブタ ンの分析について P.1066 で測定限界外と述べられて いるが現在の技術で充分測定できると思らか。

山下 全くその通りであるがこれらのガス発生量は メタンの 1/10 以下であり大まかな炭化反応を検討す る場合は必要でないので分析しなかった。

大内 (公試研) われわれの用いた試料の量とガス クロの場合は測定限界であるということである。

\title{
Carbonization Reaction of Phenol Resins and a Brown Coal
}

\author{
by Yasumasa Yamashita \& Koji Ouchi \\ (National Research Institute for Pollution and Resources)
}

SYNOPSIS : -The decomposed gases of phenol-formaldehyde retin (1), 3-methylphenol-formaldehyde resin (2) and 3,5-dimethyl-formaldehyde resin (3) with a brown coal (Tempoku coal), during their heat treatment up to $1,600^{\circ} \mathrm{C}$, were analysed gaschromatographically. (1) has a maximum of production rate at $720^{\circ} \mathrm{C}$ for hydrogen, $600^{\circ} \mathrm{C}$ for methane and carbon monoxide, and $520^{\circ} \mathrm{C}$ for water.

As a number of methyl groups of resins increases, the maximum point of methane production shifts to the lower temperature side and its quantity also increases. Similar 
phenomenon is seen in the case of water. Hydrogen and carbon monoxide do not change their maximum production temperature for all resins, but their quantity reduces with the increase of methyl groupes.

A mechanism of carbonization reaction was proposed on a ground of chain reaction.

Brown coal shows similar phenomena except relatively large quantity of carbon dioxide, and two maxima of carbon monoxide. The basical decomposition reaction and its structure may be similae as that of phenol resins, especially as (1). The activationenergy of each gases were calculated and they gave nearly same values for the same kind of gases, namely 22.9 and $34.8 \mathrm{kcal} / \mathrm{mol}$ for methane, $7.3,17.4$ and 36.6 $\mathrm{kcal} / \mathrm{mol}$ for $\mathrm{H}_{2} \mathrm{O}, 13.7$ and $36.6 \mathrm{kcal} / \mathrm{mol}$ for carbon monoxide, and $32.9 \mathrm{kcal} / \mathrm{mol}$ for hydrogen. 